\title{
Determination of the Chemical Composition and Antimicrobial Activity of Lavatera thuringiaca L. Medicinal Herb Material Extracted under Subcritical Conditions by the Liquid Carbon Dioxide Method
}

\author{
Moldir A. Zhandabayeva $\mathbb{D}^{1},{ }^{1}$ Kaldanay K. Kozhanova $\mathbb{D}^{1},{ }^{1}$ Assyl K. Boshkayeva $\mathbb{D}^{2}{ }^{2}$ \\ Valeriy A. Kataev $\mathbb{D}^{3}{ }^{3}$ Gulbaram O. Ustenova $\mathbb{D}^{4},{ }^{4}$ Nadezhda G. Gemejiyeva $\mathbb{D},{ }^{5}$ \\ and Zhanar A. Iskakbayeva $\mathbb{D i D}^{6}$ \\ ${ }^{1}$ Department of Engineering Disciplines, Asfendiyarov Kazakh National Medical University, Almaty 050000, Kazakhstan \\ ${ }^{2}$ Department of Pharmaceutical and Toxicological Chemistry, Pharmacognosy and Botany, \\ Asfendiyarov Kazakh National Medical University, Almaty 050000, Kazakhstan \\ ${ }^{3}$ Pharmaceutical Faculty, Bashkortostan State Medical University, Ufa 450000, Russia \\ ${ }^{4}$ Department of Pharmaceutical Technology, Asfendiyarov Kazakh National Medical University, Almaty 050000, Kazakhstan \\ ${ }^{5}$ Laboratory of Plant Resources, Institute of Botany and Phyto-Introductions, Almaty 050057, Kazakhstan \\ ${ }^{6}$ Laboratory of Microbiology, Scientific Center of Anti-Infectious Drugs, Almaty 050057, Kazakhstan
}

Correspondence should be addressed to Moldir A. Zhandabayeva; moti_23.91@mail.ru

Received 12 May 2021; Revised 2 July 2021; Accepted 12 July 2021; Published 22 July 2021

Academic Editor: Yingchao Su

Copyright (C) 2021 Moldir A. Zhandabayeva et al. This is an open access article distributed under the Creative Commons Attribution License, which permits unrestricted use, distribution, and reproduction in any medium, provided the original work is properly cited.

\footnotetext{
This article presents the composition of the components of Lavatera thuringiaca L. (Malvaceae Juss. family), which has a certain antibacterial effect. The plant collection was carried out in the Shamalgan gorge of Mountain Range of the Trans-Ili Alatau in the

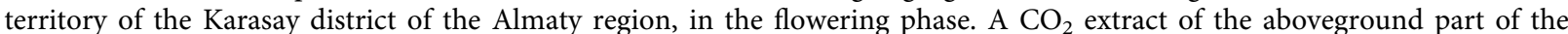
medicinal plant Lavatera thuringiaca L. was obtained under subcritical conditions and, for the first time, studied for its component composition and antimicrobial activity. Determination of the chemical composition of the extract was carried out by gas chromatography/mass spectrometry (GC/MS). To identify the obtained mass spectra, we used the Wiley $7^{\text {th }}$ edition and the NIST'02 data library. To determine the antimicrobial and antifungal activity, standard test strains of microorganisms were used: Staphylococcus aureus ATCC 6538-P, Escherichia coli ATCC 8739, Pseudomonas aeruginosa ATCC 9027, Candida albicans ATCC 10231, Streptococcus pneumonia ATCC 660, Klebsiella pneumoniae ATCC 700603, Staphylococcus haemolyticus, and Staphylococcus saprophyticus. In the composition of thick $\mathrm{CO}_{2}$ Lavatera thuringiaca L. extract, the content of 31 components was proven: spathulenol $6.97 \%$, pulegone $508 \%$, cis- $\beta$-farnesene $7.63 \%$, verbenone $1.93 \%$, $\alpha$-bisabolol oxide B $9.65 \%$, bisabolol oxide A $8.26 \%, \alpha$-bisabolol $1.36 \%$, linolenic acid, ethyl ether $3.15 \%$, phytol $2.49 \%$, herniarin $5.61 \%$, linolenic acid $9.38 \%$, linoleic acid $6.95 \%$, myristic acid $2.33 \%$, and elaidic acid $2.57 \%$. Antimicrobial activity studies have shown that the $\mathrm{CO}_{2}$ extract of Lavatera thuringiaca L. has a pronounced effect against clinically significant microorganisms: Staphylococcus aureus, Escherichia coli, Pseudomonas aeruginosa, Candida albicans, Streptococcus pneumonia, Klebsiella pneumoniae, Staphylococcus haemolyticus, and Staphylococcus saprophyticus. During testing, the method of serial dilutions proved that the extract of Lavatera thuringiaca L. has a bactericidal effect on Staphylococcus aureus at a concentration of $0.83 \mu \mathrm{g} / \mu \mathrm{l}$, on Escherichia coli at a concentration of $3.33 \mu \mathrm{g} / \mu \mathrm{l}$, on Pseudomonas aeruginosa at a concentration of $0.83 \mu \mathrm{g} / \mu \mathrm{l}$, on Streptococcus pneumoniae at a concentration of $1.67 \mu \mathrm{g} / \mu \mathrm{l}$, on a clinical isolate of Staphylococcus haemolyticus at a concentration of $26.65 \mu \mathrm{g} / \mu \mathrm{l}$, on Staphylococcus saprophyticus at a concentration of $6.67 \mu \mathrm{g} / \mu \mathrm{l}$, and against Klebsiella pneumoniae at a concentration of $13.36 \mu \mathrm{g} / \mu \mathrm{l}$. The test result showed that the extract also has fungicidal activity against the test culture of Candida albicans at a concentration of $0.21 \mu \mathrm{g} / \mu \mathrm{l}$. At tests, the disc diffusion method proved that the extract has antimicrobial activity with high values of the growth suppression zone exceeding $15 \mathrm{~mm}$. The zones of growth retardation of the test strains were $19.33 \pm 1.15$ for Staphylococcus aureus; $17.33 \pm 3.21$ for Escherichia coli; $15.67 \pm 0.57$ for
} 
Pseudomonas aeruginosa; $20.0 \pm 1.0$ for Streptococcus pneumoniae; $16.0 \pm 2.64$ for Klebsiella pneumoniae; $15.0 \pm 1.0$ for Staphylococcus saprophyticus, and $22.0 \pm 1.73$ for Candida albicans. In relation to the clinical isolate of Staphylococcus haemolyticus, the extract has a bacteriostatic effect.

\section{Introduction}

In recent decades, consumption of medicinal plants and plant-based products has been steadily growing, since they are in no way inferior in quality and biological activity to synthetic drugs [1]. Herbal preparations are able to influence the human body without disrupting the course of physiological processes. By studying biologically active substances and developing medicines from plant materials of various species, it is possible to expand the range of domestic products of plant origin and meet the need for highly effective and low-toxic herbal medicines. To solve this task, it is necessary to use our own raw materials, production facilities, and scientific and technical potential. Practical interest of the species is Lavatera thuringiaca L., which is a promising medicinal plant rich in biologically active substances.

The genus Lavatera L. from the Malvaceae Juss. family is represented by 25 species found mainly in the Mediterranean countries. Only one species, Lavatera thuringiaca L. [2], grows almost in every part of Kazakhstan's territory. This is a promising medicinal plant used in folk medicine as an anti-inflammatory, emollient, enveloping, sedative, hemostatic, and laxative [3]. It is a herbaceous multistemmed perennial of $25-200 \mathrm{~cm}$ high, covered with short stellate hairs. The stems are simple or branched in the upper half. The leaves are almost rounded, cut off at the base, and 5lobed; the upper leaves are 3-lobed; and the lobes are ovate or broadly ovate, obtuse, with a longer middle one. The flowers are solitary, large, wide open with a pink corolla and obovate, deeply bilobate petals. The seeds are reniform, dark brown, and smooth. The plant blooms in June-September. It grows in the steppe zone, in meadows, fallow lands, in thickets of bushes, on the outskirts of groves, near roads, and in low places near rivers and lakes throughout Kazakhstan. Spread area: Europe, the Mediterranean, the Balkans, the Caucasus, Central and Minor Asia, Western and Eastern Siberia, and Western China.

It is used as a technical plant for the production of fibers, suitable for the production of twine, and ropes, as well as an ornamental and honey-bearing plant [4].

Due to the high content of flavonoids, Lavatera thuringiaca L. is used in pharmaceutical practice [5] as an antitussive agent [6]. The following compounds were exported and identified from the flowers of Lavatera thuringiaca L.: kaempferol 3-O- $\beta$-glucoside, kaempferol, and quercetin 3$\mathrm{O}$-rutinoside, and two fractions containing different ratios of cis- and trans-tiliroside and para-coumaric acid. Using the high-performance liquid chromatography method, Russian scientists have identified the composition of the complex of phenolic compounds of vegetative organs and flowers of the Lavatera thuringiaca L. harvested in the Altai Territory. The roots contained derivatives of caffeic and chlorogenic acids, and umbelliferone; the grass and stems contained derivatives of chlorogenic acid, flavonoids of the flavone and catechin groups, and coumarin compounds; the leaves contained derivatives of chlorogenic and ferulic acids and derivatives of quercetin (quercitrin, etc.), kaempferol, and flavone; and the flowers contained phenologlycosides and kaempferol and flavone derivatives [7]. This plant has abundant polyphenolic compounds; flavonoids; pronounced antioxidants [8]; and anti-inflammatory [9], antimicrobial [10], antibacterial [11], cytotoxic [12], and other types of activity. The plant extracts of the genus Lavatera of the Malvaceae family obtained by the method of Soxhlet, maceration, microwave, ultrasonic, and subcritical water extraction are used in medicine as agents for the treatment of infectious diseases [13] and cancer [14] and also have antioxidant, cytotoxic, and antibacterial activity.

Thus, a review of the literature indicates that the research conducted by foreign scientists does not provide solid information on the presence of terpenes that determine the composition of the plant and extracts obtained from the species Lavatera thuringiaca L. The $\mathrm{CO}_{2}$-extraction method proposed for improving the extraction and selectivity of plant bioactive compounds [15] is an indispensable method for detecting terpene classes.

Earlier, foreign scientists [12] obtained extracts from the plant-based raw materials of medicinal plant Lavatera thuringiaca L. by methods of Soxhlet, maceration, microwave, ultrasonic, and subcritical water extraction. When determining the component composition of these obtained extracts, the class of terpenes was not identified. Flavonoids were not determined in the chemical composition of Lavatera thuringiaca L. extract by HPLC. The quantitative analysis carried out by the GC/MS method shows a negative result for the content of flavonoids. During this study, a thick extract of $\mathrm{CO}_{2}$ was obtained under subcritical conditions from the aboveground parts of Lavatera thuringiaca L.; along with this, the component composition was studied, 31 chemical compounds and terpenes were identified and lastly, antimicrobial activity against pathogenic bacteria was established.

\section{Materials and Methods}

2.1. The Plant Material. The plant material of the aboveground part of Lavatera thuringiaca L. was collected during its flowering phase in the Shamalgan gorge of the Zailiyskiy Alatau ridge on the territory of the Karasay district of the Almaty region in June 2018. The coordinates of the places of growth and collection of the raw material studied were 
determined using a GPS navigator (point 1: $\mathrm{N} 43^{\circ} 12^{\prime} 27.34^{\prime \prime}$, E $76^{\circ} 33^{\prime} 55.36^{\prime \prime}$, point 2 : $\mathrm{N} 43^{\circ} 10^{\prime} 36.06^{\prime \prime}$, E $76^{\circ} 31^{\prime} 0.45^{\prime \prime}$, point 3: $\mathrm{N} 43^{\circ} 11^{\prime} 21.12^{\prime \prime}$, E $76^{\circ} 30^{\prime} 37.17^{\prime \prime}$ ).

The collected vegetable plant materials were dried at a temperature of $+25 \pm 5^{\circ} \mathrm{C}$ naturally in the shade, in a wellventilated place. The moisture content of the plant-based raw materials does not exceed $10 \%$. The dried plant material was crushed on a KDU-2 crusher and stored at a temperature of $+15^{\circ} \mathrm{C}$ to $25^{\circ} \mathrm{C}$ and a humidity of no more than $65 \%$ in paper bags.

Plant samples were identified at the Institute of Botany and Phyto-Introduction (Almaty) (registration number of reference No. 01-08/273).

2.2. Preparation of Carbon Dioxide Extract. The dried above ground part of Lavatera thuringiaca $L$., which was harvested in June 2018, was used as a medicinal plant raw material for the production of carbon dioxide extraction. The extract was obtained in the production base of the limited liability partnership "production of medicines Zhanafarm." The extract was received under subcritical conditions on a $5-\mathrm{L}$ laboratory machine for $\mathrm{CO}_{2}$ flow-through extraction in accordance with the Company's SS 8050-85 Standard. Liquid carbon dioxide was used as an extractant. Optimal conditions for obtaining the $\mathrm{CO}_{2}$ extract were maintained: pressure of 51-65 atmospheres, temperature of $18-27^{\circ} \mathrm{C}$, and extraction time of 7-11 hours.

To increase the specific contact surface of the extracted raw material with liquid $\mathrm{CO}_{2}$, the grass was crushed on the KDU-2 crusher. The particle size of the plant-based raw material is $1-3 \mathrm{~mm}$. To obtain a thick carbon dioxide extract of the Lavatera thuringiaca L. herb, $2000 \mathrm{~g}$ of raw material was taken, from which $25 \mathrm{~g}$ of extract was obtained; that is, the yield constituted $1.25 \%$.

2.2.1. Extraction Procedure. The shredded plant material was loaded into an UUPE-5L extractor (a laboratory carbon dioxide flow extraction machine). The extraction was carried out with carbon dioxide under the conditions specified for this process. Liquefied carbon dioxide was delivered from the storage tank using a high-pressure pump at a pressure of $6 \mathrm{MPa}$ and entered the extractor tank. From the extractor, the flow with the substances dissolved in carbon dioxide was fed to the collectors, where the process of separating the solvent and solute was carried out with sequential pressure relief. The extract was deposited into collectors and then discharged as a finished product.

\subsection{Determination of the Component Composition of the} Extract. Gas chromatography with mass spectrometric detection (Agilent 7890A/5975C) was used for the qualitative and quantitative analysis of the carbon dioxide extract of Lavatera thuringiaca L. Chromatographic analysis conditions are as follows: sample volume of $-1.0 \mu \mathrm{l}$, sample injection temperature of $-240^{\circ} \mathrm{C}$, and flow division of $-1: 10$. Separation was carried out using a 30-metre long WAXetr chromatographic capillary column, with an inner diameter of $0.25 \mathrm{~mm}$ and a film thickness of $0.25 \mu \mathrm{m}$ at a constant gas carrier (helium) velocity of $1 \mathrm{ml} / \mathrm{min}$. The chromatographic temperature was programmed from $40^{\circ} \mathrm{C}(0 \mathrm{~min}$ exposure) to $260^{\circ} \mathrm{C}$ with a heating rate of $10^{\circ} \mathrm{C} / \mathrm{min}(20 \mathrm{~min}$ exposure). Detection was performed in the SCAN $m / z$ 34-850 mode. Agilent MSD ChemStation software (version 1701EA) was used to control the gas chromatography system, register the results, and process the data. Data processing included the determination of retention times, peak areas, and verification of spectral information obtained with the mass spectrometric detector.

2.3.1. Identification of the Component Composition of the Extract. To identify the obtained mass spectra, we used the Wiley $7^{\text {th }}$ edition and NIST'02 data libraries. The components were identified by the mass spectrum and retention time.

2.3.2. Quantitative Determination. For the quantitative determination of terpenes in the $\mathrm{CO}_{2}$ extract, the gas chromatography method with mass spectrometric detection (Agilent 7890A/5975C) was used. The percentage of components was calculated automatically based on the peak areas of the total ion chromatogram.

The content of the sum of terpenes in the extract should be at least $50.0 \%$.

2.4. Determination of Antimicrobial Activity. To determine the antimicrobial activity, standard test strains of microorganisms were used: Pseudomonas aeruginosa ATCC 9027, Candida albicans ATCC 10231, Escherichia coli ATCC 8739, Streptococcus pneumonia ATCC 660, and Klebsiella pneumoniae ATCC 700603, obtained from the American Type Culture Collection (ATCC, USA), and Staphylococcus aureus ATCC 6538-P, Staphylococcus haemolyticus, and Staphylococcus saprophyticus, obtained from the Republican Collection of Microorganisms (Nur-Sultan, Kazakhstan).

Studies of the sensitivity of microorganisms were carried out on standard nutrient media:

(i) Mueller-Hinton medium: Mueller-Hinton agar (M173), HiMedia, India

(ii) Mueller-Hinton broth (M391), HiMedia, India

(iii) Sabouraud liquid medium (M033), HiMedia, India

The antimicrobial activity of the carbon dioxide extract of Lavatera thuringiaca L. was determined by two methods: the method of serial dilution and the disk-diffusion method.

2.4.1. Definition of the Extract's Antimicrobial Activity by the Serial Dilution Method. To determine antimicrobial activity, a 96-well plate was used. In all wells, except for the first ones, it was required to add the Mueller-Hinton nutrient broth (M391) (for testing bacteria) and Sabouraud broth (for testing fungi), in the amount of $100 \mu \mathrm{l}$ (from the $1^{\text {st }}$ to the $12^{\text {th }}$ wells). The extract was preliminarily dissolved in $0.5 \mathrm{ml}$ of $0.9 \%$ sodium chloride solution and introduced in the 
volume of $100 \mu$ into the $1^{\text {st }}$ well, making serial dilutions by taking the mixture (Mueller-Hinton broth/Sabourauddextrose broth $(100 \mu \mathrm{l})+$ test drug $(100 \mu \mathrm{l}))$ from the $1^{\text {st }}$ well in the amount of $100 \mathrm{mcl}$ into the $2^{\text {nd }}$ well, already containing $100 \mathrm{mcl}$ of the broth. The test sample was thoroughly mixed and then $100 \mu \mathrm{l}$ of it was transferred into the broth from the $2^{\text {nd }}$ well to the $3^{\text {rd }}$ well, which also initially contained $100 \mu$ l of the broth. This procedure was repeated until the required number of dilutions was reached. $50 \mu \mathrm{l}$ of the mixture was removed from the last well. Thus, the following dilutions were obtained: $1: 1,1: 2 ; 1: 4,1: 8,1: 16,1: 32,1$ : $64,1: 128,1: 256,1: 512,1: 1024$, which corresponds to the wells from 1 to 11 . The $12^{\text {th }}$ well was for the test strain control.

After a series of dilutions, $20 \mu \mathrm{l}$ of test strains of microorganisms at a concentration of $1.5 \times 10^{6} \mathrm{CFU} / \mathrm{ml}$ was added to all wells (Figure 1).

All the samples were incubated for 18-24 hours at $37 \pm 1^{\circ} \mathrm{C}$. After the incubation time, the samples were plated on Petri dishes with Mueller-Hinton nutrient medium to determine living cells. The results were taken into account by the presence of visible growth of microorganisms on the surface of a dense nutrient medium.

The minimum bactericidal concentration (MBC) was considered the lowest concentration in a test tube that suppressed the growth of microorganisms. Table 1 shows the labelling of Petri dishes according to dilutions.

2.4.2. Determination of Antimicrobial Activity by the Disk-Diffusion Method. The disk-diffusion method was carried out by applying the discs treated with the preparation on Petri dishes using sterile forceps at a distance of $15-20 \mathrm{~mm}$ from the dish edge and from each other. The Petri dishes were preinoculated with the test strains suspension with a density of $1.5 \times 10^{8} \mathrm{CFU} / \mathrm{ml}$. For inoculation, sterile cotton swabs were immersed in the suspension and then slightly pressed against the test tube walls and streaked in three directions, turning the cup by $60^{\circ}$. Cartridges with ready-made sterile discs (HiMedia) were used in the study. The disks were preliminarily saturated with the extract within the exposure time of approximately $30 \mathrm{~min}$.

After inoculation, the dishes were placed in a thermostat for incubation of bacteria for $18-24$ hours at $37^{\circ} \mathrm{C}$. The results of the disc diffusion method were taken into account by calculating zones diameter of retardation/suppression growth with an accuracy of $1 \mathrm{~mm}$ (Performance Standards for Antimicrobial Susceptibility Testing, 2015; Guidelines for determining the sensitivity of microorganisms to antibacterial drugs, 2004; Reference Method for Broth Dilution Antifungal Susceptibility Testing of Yeast, 2017) [16-18].

\section{Results and Discussion}

3.1. Determination of the Component Composition of the $\mathrm{CO}_{2}$ Extract. To obtain the extract, we analyzed the extraction capacity of carbon dioxide under sub- and supercritical conditions and various physical parameters. The results are shown in Table 2.

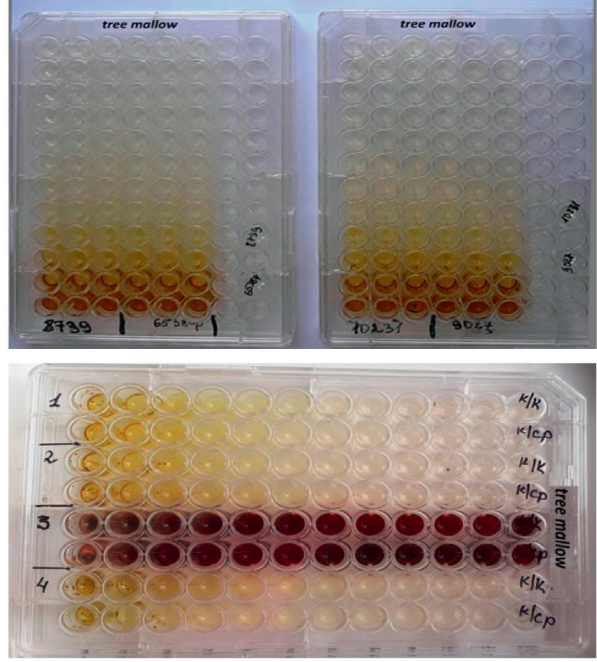

FIgURe 1: Setting antimicrobial activity in a 96-well plate.

The study shows that out of all 5 obtained carbon dioxide extracts of Lavatera thuringiaca L. under subcritical conditions, according to the output data parameters, chemical composition, and technological parameters, extract No.1 is optimal. Thus, when obtaining an extract from the herb Lavatera thuringiaca L. it was found that the yield of the extract under subcritical conditions is significantly higher than other production methods (supercritical $\mathrm{CO}_{2}$ extraction). For comparison, we took one sample of the extract obtained under supercritical conditions.

Figure 2 and Table 3 show the results of a study of the chemical composition of a thick extract obtained from the medicinal plant raw material Lavatera thuringiaca $\mathrm{L}$. The content of 31 compounds was determined by chromatography-mass spectrometry. We studied the pharmacological activity of these compounds by analyzing the works of foreign scientists.

Monoterpenes: isopulegone $0.7 \%$, pulegone $5.08 \%$, and verbenone 1.93\%; diterpenes: phytol $2.49 \%$; sesquiterpenes: bisabolol oxide A $8.26 \%, \alpha$-bisabolol oxide B 9.65\%, $\gamma$-muurolene $0.75 \%$, spathulenol $6.97 \%$, cis- $\beta$-farnesene $7.63 \%$, and alloaromadendrene $0.4 \%$; fatty acids: linolenic acid $9.38 \%$, linoleic acid $6.95 \%$, elaidic acid $2.57 \%$, stearic acid $1.14 \%$, myristic acid $2.33 \%$, palmitic acid, and ethyl ester 2.72\%; and coumarins: herniarin or 7-methoxycoumarin $5.61 \%$ were found among the main classes of compounds $\mathrm{CO}_{2}$ extract of Lavatera thuringiaca $\mathrm{L}$.

3.2. Results of Determination of the Antimicrobial Activity of the $\mathrm{CO}_{2}$ Extract. Antimicrobial activity was studied on the $\mathrm{CO}_{2}$ extract of Lavatera thuringiaca $\mathrm{L}$. The main active ingredients of the extract Lavatera thuringiaca L. are as follows: compounds of terpenes $53.3 \%$, fatty acids $28.55 \%$, and coumarins $5.61 \%$ with a supposed antimicrobial effect.

When studying the antimicrobial activity by the method of serial dilutions, the antibacterial and fungicidal effect of $\mathrm{CO}_{2}$ extract of Lavatera thuringiaca L. was established in relation to the analyzed strains of microorganisms 
TABLe 1: Labelling of Petri dishes according to dilutions.

\begin{tabular}{|c|c|c|c|c|c|c|c|c|c|c|c|c|}
\hline No. of wells & $\begin{array}{c}\text { Well } \\
1\end{array}$ & $\begin{array}{c}\text { Well } \\
2\end{array}$ & $\begin{array}{c}\text { Well } \\
3\end{array}$ & $\begin{array}{c}\text { Well } \\
4\end{array}$ & $\begin{array}{c}\text { Well } \\
5\end{array}$ & $\begin{array}{c}\text { Well } \\
6\end{array}$ & $\begin{array}{c}\text { Well } \\
7\end{array}$ & $\begin{array}{c}\text { Well } \\
8\end{array}$ & $\begin{array}{c}\text { Well } \\
9\end{array}$ & $\begin{array}{c}\text { Well } \\
10\end{array}$ & $\begin{array}{c}\text { Well } \\
11\end{array}$ & Well 12 \\
\hline $\begin{array}{l}\text { Dilution of the test sample and } \\
\text { Mueller-Hinton broth/Sabouraud } \\
\text { broth }\end{array}$ & $1: 1$ & $1: 2$ & $1: 4$ & $1: 8$ & $1: 16$ & $1: 32$ & $1: 64$ & $\begin{array}{c}1: \\
128\end{array}$ & $\begin{array}{c}1: \\
256\end{array}$ & $1: 512$ & $\begin{array}{c}1: \\
1024\end{array}$ & $\begin{array}{c}\text { Test strain } \\
\text { control }\end{array}$ \\
\hline
\end{tabular}

TABLE 2: Extract yield at different parameters of subcritical and supercritical extraction.

\begin{tabular}{|c|c|c|c|c|c|}
\hline \multirow{2}{*}{$\begin{array}{l}\text { Extraction samples } \\
\text { obtained (thick extract) }\end{array}$} & \multicolumn{4}{|c|}{ Parameters } & \multirow[b]{2}{*}{$\begin{array}{l}\text { Extract yield } \\
\quad(g)(\%)\end{array}$} \\
\hline & $\begin{array}{l}\text { Weight of the plant } \\
\text { material }(\mathrm{g})\end{array}$ & $\begin{array}{l}\text { Working pressure } \\
\text { (atmospheres) }\end{array}$ & $\begin{array}{l}\text { Extraction process } \\
\text { temperature }\left({ }^{\circ} \mathrm{C}\right)\end{array}$ & $\begin{array}{l}\text { Extraction progress } \\
\text { time (hours) }\end{array}$ & \\
\hline \multicolumn{6}{|c|}{ Subcritical $\mathrm{CO}_{2}$ extraction (thick extract) } \\
\hline No. 1 & 2,000 & 51 & 21 & 11 & $25(1.25)$ \\
\hline No. 2 & 1,900 & 56 & 18 & 7 & $12(0.63)$ \\
\hline No. 3 & 1,850 & 60 & 20 & 9 & $10(0.54)$ \\
\hline No. 4 & 1,800 & 63 & 21 & 10 & $7(0.38)$ \\
\hline No. 5 & 1,700 & 65 & 21 & 11 & $6(0.35)$ \\
\hline \multicolumn{6}{|c|}{ Supercritical $\mathrm{CO}_{2}$ extraction (thick extract) } \\
\hline No. 1 & 2,000 & 98.69 & 50 & More than 1 & $12(0.63)$ \\
\hline
\end{tabular}

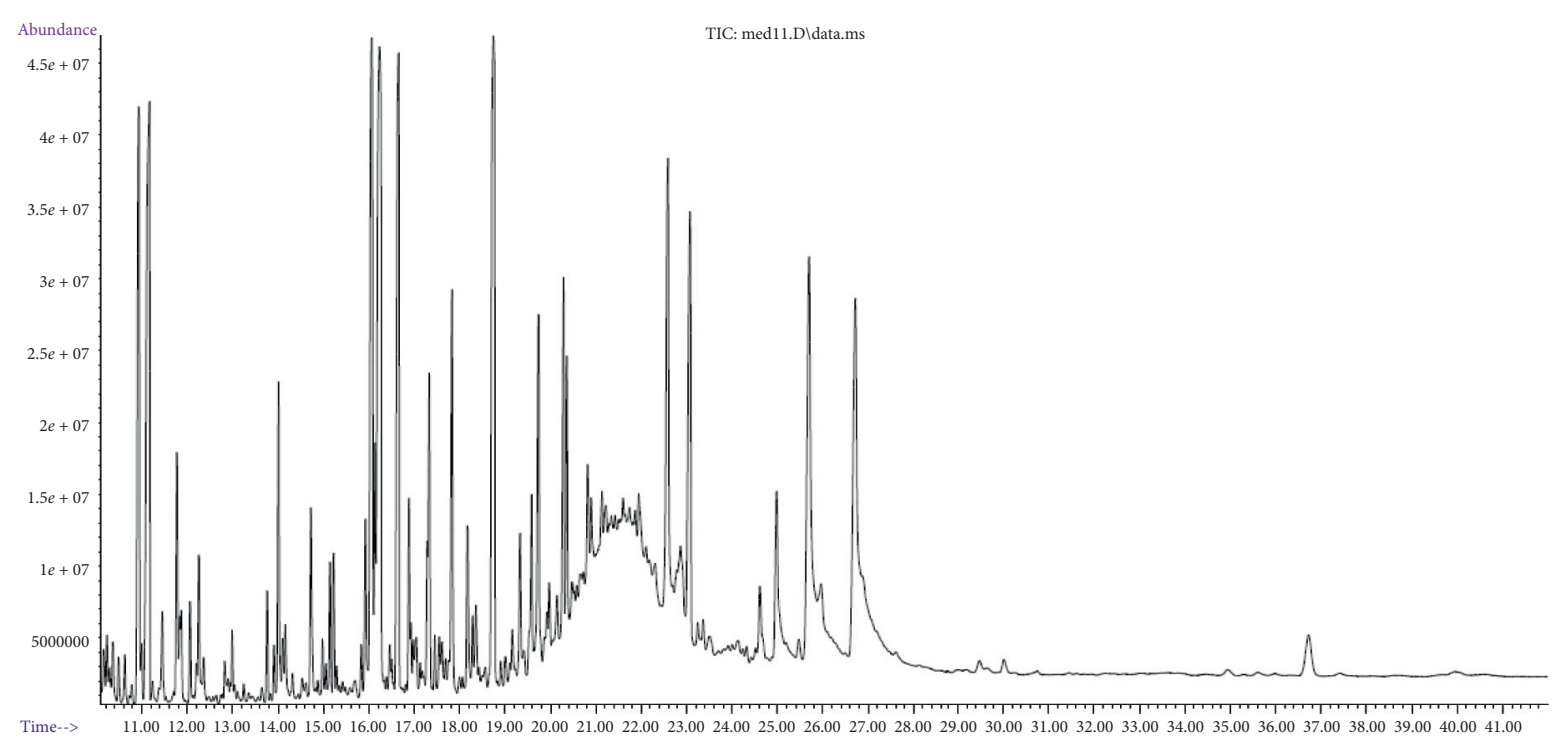

Figure 2: The analysis chromatogram of the Lavatera thuringiaca $\mathrm{L}$ subcritical $\mathrm{CO}_{2}$ extract.

Staphylococcus aureus ATCC 6538-P, Escherichia coli ATCC 8739, Pseudomonas aeruginosa ATCC 9027, Candida albicans ATCC 10231, Streptococcus pneumoniae ATCC 660, Klebsiella pneumoniae ATCC 700603, Staphylococcus haemolyticus, and Staphylococcus saprophyticus (Table 4).

The results of the study of antimicrobial activity by serial dilution showed that the $\mathrm{CO}_{2}$ extract of Lavatera thuringiaca L. has the greatest bactericidal and bacteriostatic effectiveness against Candida albicans at a concentration of 0.21 $\mathrm{mcg} / \mathrm{ml}$; Pseudomonas aeruginosa at a concentration of $0.83 \mu \mathrm{g} / \mu \mathrm{l}$; Staphylococcus aureus at a concentration of $0.83 \mu \mathrm{g} / \mu \mathrm{l}$; Streptococcus pneumoniae at a concentration of $1.67 \mu \mathrm{g} / \mu \mathrm{l}$; Escherichia coli at a concentration of $3.33 \mu \mathrm{g} / \mu \mathrm{l}$; Staphylococcus saprophyticus at concentrations of $6.67 \mu \mathrm{g} / \mu \mathrm{l}$ and $3.33 \mu \mathrm{g} / \mu \mathrm{l}$; Klebsiella pneumoniae at concentrations of
$13.36 \mu \mathrm{g} / \mu \mathrm{l}$ and $6.67 \mu \mathrm{g} / \mu \mathrm{l}$; and Staphylococcus haemolyticus at concentrations of $26.65 \mu \mathrm{g} / \mu \mathrm{l}$ and $13.36 \mu \mathrm{g} / \mu \mathrm{l}$.

Studying the antimicrobial activity of the $\mathrm{CO}_{2}$ extract of Lavatera thuringiaca L. was carried out by the method of serial dilutions and the antimicrobial activity of the extract was established by the disk-diffusion method (Table 5).

The testing by the disk-diffusion method revealed that the extract had an antimicrobial activity with high values of the growth suppression zone exceeding $15 \mathrm{~mm}$. The growth inhibition zones of the test strains were $19.33 \pm 1.15$ against Staphylococcus aureus ATCC 6538-p., 17.33 \pm 3.21 against Escherichia coli ATCC 8739, $15.67 \pm 0.57$ against Pseudomonas aeruginosa ATCC 9027, $20.0 \pm 1.0$ against Streptococcus pneumoniae ATCC 660, $16.0 \pm 2.64$ against Klebsiella pneumoniae ATCC 700603, and 15.0 \pm 1.0 against 
TABLE 3: The results of the chromatographic analysis of the Lavatera thuringiaca $\mathrm{L}$. subcritical $\mathrm{CO}_{2}$ extract.

\begin{tabular}{|c|c|c|c|c|c|c|}
\hline No. & $\begin{array}{c}\mathrm{RT} \\
(\mathrm{min})\end{array}$ & Name of compound & The class & Activity & $\begin{array}{l}\text { PubChem } \\
\text { CID }\end{array}$ & $(\%)$ \\
\hline 1 & 10.2 & Isopulegone & Monoterpenoid & $\begin{array}{l}\text { Anticonvulsant, anti-inflammatory, antioxidant, } \\
\text { gastroprotective, antistress [19-21] }\end{array}$ & 34645 & 0.7 \\
\hline 2 & 10.2 & D-Menthol & Terpene & Anti-irritant, pain-reliever [22-24] & 165675 & 0.8 \\
\hline 3 & 10.5 & Alloaromadendrene & Sesquiterpene & Antioxidant [25] & 42608158 & 0.4 \\
\hline 4 & 10.9 & Pulegone & Monoterpene & Antinociceptive [26] & 442495 & 5.08 \\
\hline 5 & 11.2 & Cis- $\beta$-farnesene & Sesquiterpene & Antifungal [27] & 5317319 & 7.63 \\
\hline 6 & 11.2 & Humulene & Terpene & $\begin{array}{c}\text { Anti-inflammatory, appetite suppressant, pain } \\
\text { reliever }[28,29]\end{array}$ & 5281520 & 0.19 \\
\hline 7 & 14.0 & Verbenone & Monoterpene & Antimicrobial, antifungal, anticonvulsive [30-32] & 29025 & 1.93 \\
\hline 8 & 14.7 & Caryophyllene oxide & Terpene & $\begin{array}{l}\text { Anticancer and analgesic, anti-inflammatory } \\
\qquad[33,34]\end{array}$ & 1742210 & 1.35 \\
\hline 9 & 15.2 & E-Nerolidol & Terpene & Antifungal, sedative $[35,36]$ & 5281525 & 0.80 \\
\hline 10 & 16.1 & Spathulenol & Sesquiterpenoid & $\begin{array}{c}\text { Antioxidant, anti-inflammatory, antiproliferative, } \\
\text { and antimycobacterial [37] }\end{array}$ & 92231 & 6.97 \\
\hline 11 & 16.2 & $\alpha$-Bisabolol oxide B & Sesquiterpene & $\begin{array}{c}\text { Anti-irritant, anti-inflammatory, and } \\
\text { antimicrobial [38-41] }\end{array}$ & 6432283 & 9.65 \\
\hline 12 & 16.9 & $\alpha$-Bisabolol & Terpene & $\begin{array}{c}\text { Anti-irritant, anti-inflammatory, antimicrobial, } \\
\text { analgesic [38-41] }\end{array}$ & 10586 & 1.36 \\
\hline 13 & 18.7 & Bisabolol oxide A & Sesquiterpene & $\begin{array}{c}\text { Anti-irritant, anti-inflammatory, and } \\
\text { antimicrobial [38-41] }\end{array}$ & 13092559 & 8.26 \\
\hline 14 & 17.3 & Palmitic acid, ethyl ester & Fatty acid & Anti-inflammatory $[42]$ & 12366 & 2.72 \\
\hline 15 & 20.3 & Linolenic acid, ethyl ester & Fatty acid & $\begin{array}{l}\text { Promitogeinc and activating effects on hepatic } \\
\text { stellate cells (HSC), anticancer }[43,44]\end{array}$ & 5367460 & 3.15 \\
\hline 16 & 20.4 & Phytol & Terpene & Anti-inflammatory, analgesic $[45,46]$ & 5280435 & 2.49 \\
\hline 17 & 20.9 & Myristic acid & Saturated fatty acid & Antimicrobial [47] & 11005 & 2.33 \\
\hline 18 & 23.1 & $\begin{array}{l}\text { Herniarin or } 7 \text { - } \\
\text { methoxycoumarin }\end{array}$ & Coumarin & $\begin{array}{l}\text { Antigenotoxic, anti-inflammatory, antinociceptive } \\
\qquad[48-50]\end{array}$ & 10748 & 5.61 \\
\hline 19 & 24.6 & Stearic acid & Saturated fatty acid & Anticancer [51] & 5281 & 1.14 \\
\hline 20 & 25.0 & Elaidic acid & Saturated fatty acid & Against herpesviruses [52] & 637517 & 2.57 \\
\hline 21 & 25.7 & Linoleic acid & $\begin{array}{l}\text { Polyunsaturated fatty } \\
\text { acid }\end{array}$ & Anti-inflammatory, antibacterial [53-55] & 5280450 & 6.95 \\
\hline 22 & 26.7 & Linolenic acid & Fatty acid & $\begin{array}{l}\text { Inflammatory, antioxidant, cytotoxic, } \\
\text { antibacterial, and antifungal }[53,54,56]\end{array}$ & 5280934 & 9.38 \\
\hline 23 & 36.7 & Cannabidiol & Phytoc & Anticonvulsant [57] & 644019 & 0.96 \\
\hline 24 & 11.5 & $\gamma$-Muurolene & Sesquiterpene & Antimicrobial, anti-inflammatory [58] & 12313020 & 0.75 \\
\hline 25 & 11.9 & Piperitone & Monoterpenoid & $\begin{array}{c}\text { Antimicrobial, antiviral, perfume compositions } \\
\text { [59] }\end{array}$ & 6987 & 0.98 \\
\hline 26 & 16.1 & Perhydrofarnesyl acetone & & Perfume composition & 10408 & 1.36 \\
\hline 27 & 10.4 & Isocaryophyllene & Sesquiterpene & Antifungal & 5281522 & 0.36 \\
\hline 28 & 11.0 & Isovaleric acid & Fatty acid & $\begin{array}{c}\text { Sedative, used in the production of validol, } \\
\text { valocordin }\end{array}$ & 10430 & 0.31 \\
\hline 29 & 12.4 & $\alpha$-Curcumene & Sesquiterpene & Antimicrobial, anti-inflammatory, antifungal & 92139 & 0.35 \\
\hline 30 & 14.1 & Geranyl linalool & Diterpene & Antimicrobial, anti-inflammatory & 5365872 & 0.39 \\
\hline 31 & 16.5 & Thymol & Monoterpene & Antiseptic, antibacterial, and antifungal & 6989 & 0.54 \\
\hline
\end{tabular}

TABLE 4: The antimicrobial activity results of the extract $\left(\mathrm{CO}_{2}\right.$ extraction) obtained by the method of serial dilution.

Test strains

Minimum dilution of the thuringian tree mallow extract $(\mu \mathrm{g} / \mu \mathrm{l})$

Staphylococcus aureus ATCC 6538-P

Bactericidal action

Bacteriostatic action

Escherichia coli ATCC 8739

$0.83 \quad 0.83$

Pseudomonas aeruginosa ATCC 9027

3.33

3.33

Candida albicans ATCC 10231

0.83

0.83

Streptococcus pneumoniae ATCC 660

0.21

0.21

Klebsiella pneumoniae ATCC 700603

1.67

1.67

Staphylococcus haemolyticus

13.36

6.67

26.65

13.36

Staphylococcus saprophyticus

6.67 3.33 
TABLE 5: The antimicrobial activity results of the extract $\left(\mathrm{CO}_{2}\right.$ extraction) obtained by the disc diffusion method.

\begin{tabular}{lc}
\hline Test sample & Minimum bactericidal concentration (1:1 extract dilution) \\
\hline Staphylococcus aureus ATCC 6538-P & $19.33 \pm 1.15$ \\
Escherichia coli ATCC 8739 & $17.33 \pm 3.21$ \\
Pseudomonas aeruginosa ATCC 9027 & $15.67 \pm 0.57$ \\
Candida albicans ATCC 10231 & $22.0 \pm 1.73$ \\
Streptococcus pneumoniae ATCC 660 & $20.0 \pm 1.0$ \\
Klebsiella pneumoniae ATCC 700603 & $16.0 \pm 2.64$ \\
Staphylococcus haemolyticus & - \\
Staphylococcus saprophyticus & $15.0 \pm 1.0$ \\
\hline
\end{tabular}

Staphylococcus saprophyticus. Also, this extract has a bacteriostatic effect against the clinical isolate of Staphylococcus haemolyticus and fungicidal activity against Candida albicans ATCC 10231 with a growth retardation zone of $22.0 \pm 1.73$. When interpreting the data, it was conditionally assumed that the diameter of the growth retardation zone of more than $15 \mathrm{~mm}$ proves high antimicrobial activity; $10-15 \mathrm{~mm}$, average antimicrobial activity; and less than $10 \mathrm{~mm}$, low antimicrobial activity [60].

The antimicrobial activity of the obtained extracts was compared with other extracts obtained by Serbian scientists Pavle Z. Mašković and others. Five different extractive methods were used to obtain the extracts: Soxhlet, maceration, ultrasonic, microwave, and subcritical water extraction. The component composition of these extracts was determined by the HPLC-DAD method. The antibacterial activity of these extracts was tested in vitro against the following Gram-positive bacteria: Staphylococcus saprophyticus, Staphylococcus aureus, Listeria ivanovii, Listeria inocun, Enterococcus faecalis, Listeria monocytogenes, $\mathrm{Ba}$ cillus spizizenii, and Enterococcus faecium, as well as the following Gram-negative bacteria: Escherichia coli, Salmonella enteritidis, Enterobacter aerogenes, Citrobacter freundii, Salmonella typhimurium, Pseudomonas aeruginosa, and Proteus mirabilis. According to the results of these studies, the highest activity of the extract obtained by subcritical water extraction was observed for Staphylococcus saprophyticus (at a concentration of $7.81 \mu \mathrm{g} / \mu \mathrm{l}$ ). Ultrasonic extraction had the strongest effect on Salmonella typhimurium (in the concentric $7.81 \mu \mathrm{g} / \mu \mathrm{l}$ ). Maceration extraction had a strong effect on Enterobacter aerogenes (at a concentration of $15.82 \mu \mathrm{g} / \mu \mathrm{l}$ ), Proteus mirabilis (at a concentration of $7.81 \mu \mathrm{g}$ / $\mu \mathrm{l}$, and Staphylococcus saprophyticus (at a concentration of $15.82 \mu \mathrm{g} / \mu \mathrm{l})$. Soxhlet extract has been proven to be highly effective against Salmonella enteritidis.

A comparative analysis of our data with the data obtained by Serbian scientists shows the following results: the extract obtained by Serbian scientists by ultrasonic extraction shows a high bactericidal ability on Staphylococcus aureus at a concentration of $31.25 \mu \mathrm{g} / \mu \mathrm{l}$; the extract obtained by Serbian scientists using microwave and subcritical water extraction methods shows bactericidal activity on Staphylococcus aureus at a concentration of $62.50 \mu \mathrm{g} / \mu \mathrm{l}$, and in the extract obtained by $\mathrm{CO}_{2}$ extraction under subcritical conditions, the bactericidal activity on Staphylococcus aureus was proven at a concentration of $0.83 \mu \mathrm{g} / \mu \mathrm{l}$; the extract obtained by Serbian scientists by ultrasonic extraction acts on Pseudomonas aeruginosa at a concentration of $15.82 \mu \mathrm{g} /$ $\mu \mathrm{l}$; the extract obtained by Serbian scientists using microwave and subcritical water extraction methods acts on Pseudomonas aeruginosa at a concentration of $62.50 \mu \mathrm{g} / \mu \mathrm{l}$; in the extract obtained by $\mathrm{CO}_{2}$ extraction under subcritical conditions, the bactericidal activity on Pseudomonas aeruginosa is at a concentration of $0.83 \mu \mathrm{g} / \mu \mathrm{l}$; the extract obtained by Serbian scientists using ultrasonic extraction and maceration methods acts on Escherichia coli at a concentration of $62.50 \mu \mathrm{g} / \mu \mathrm{l}$; and in the extract obtained by $\mathrm{CO}_{2}$ extraction under subcritical conditions, the bactericidal activity on Escherichia coli is at a concentration of $3.33 \mu \mathrm{g} / \mu \mathrm{l}$. According to the presented data, the extract obtained by $\mathrm{CO}_{2}$ extraction under subcritical conditions has a higher antimicrobial activity than the extract obtained by Serbian scientists using the following methods: ultrasonic, subcritical water, microwave, and maceration extraction (Table 6). 
TABLE 6: Comparative analysis of the results of antimicrobial activity of extracts obtained by extraction methods.

\begin{tabular}{|c|c|c|c|c|c|}
\hline \multirow{2}{*}{ Test sample } & \multicolumn{5}{|c|}{ Minimum concentration of Lavatera thuringiaca L. extracts $(\mu \mathrm{g} / \mu \mathrm{l})$} \\
\hline & Ultrasonic extraction & Subcritical water extraction & Microwave extraction & Maceration extraction & $\mathrm{CO}_{2}$ extraction under subcritical conditions \\
\hline Staphylococcus aureus & 31.25 & 62.50 & 62.50 & 125 & 0.83 \\
\hline Pseudomonas aeruginosa & 15.82 & 62.50 & 62.50 & 250 & 0.83 \\
\hline Escherichia coli & 62.50 & 125 & 250 & 62.50 & 3.33 \\
\hline
\end{tabular}

\section{Conclusion}

The optimal conditions for $\mathrm{CO}_{2}$ extraction of carbon dioxide extract from Lavatera thuringiaca L. medicinal plant raw materials have been developed. The yield of the resulting finished product is $25 \mathrm{~g}(1.25 \%)$. This method improves the quality of the finished product. The study of subcritical $\mathrm{CO}_{2}$ extracts has shown that they do not contain ballast substances and organic solvent residues. They contain natural biologically active substances that are not exposed to temperature and chemical influences, as well as having antimicrobial activity.

To study the phytochemical composition of the Lavatera thuringiaca L. medicinal plant material, thick extracts were obtained by the $\mathrm{CO}_{2}$-extraction method and the chemical composition was determined by gas chromatography with the mass spectrometric detector. As a result, a large amount of terpenes, coumarins, and polyunsaturated fatty acids were detected in the subcritical $\mathrm{CO}_{2}$ extract. 31 components of the group of monoterpenes, diterpenes, sesquiterpenes, fatty acids, and coumarins from raw materials of Lavatera thuringiaca L. were identified.

The antibacterial activity of the $\mathrm{CO}_{2}$ extract of Lavatera thuringiaca L. obtained under subcritical conditions was determined. The tested sample of the Lavatera thuringiaca L. extract exhibits antimicrobial activity against Staphylococcus aureus ATCC 6538-p, Escherichia coli ATCC 8739, Pseudomonas aeruginosa ATCC 9027, Streptococcus pneumoniae ATCC 660, Staphylococcus haemolyticus, Staphylococcus saprophyticus, and Klebsiella pneumoniae ATCC 700603 both by serial dilution in broth and by diffusion testing in agar, forming the zones of test strains growth inhibition. This sample also exhibits fungicidal activity against the Candida albicans ATCC 10231 test culture by serial dilution and agar diffusion.

The Lavatera thuringiaca L. extract was active against all the test strains (both museum and clinical). It has been experimentally shown that the extract of Lavatera thuringiaca L., when tested by the serial dilutions method, has a bactericidal effect at the following dilutions: on Staphylococcus aureus at a concentration of $0.83 \mu \mathrm{g} / \mu \mathrm{l}$, on Escherichia coli at a concentration of $3.33 \mu \mathrm{g} / \mu \mathrm{l}$, on Pseudomonas aeruginosa at a concentration of $0.83 \mu \mathrm{g} / \mu \mathrm{l}$, on Streptococcus pneumoniae at a concentration of $1.67 \mu \mathrm{g} / \mu \mathrm{l}$, on a clinical isolate of Staphylococcus haemolyticus at a concentration of $26.65 \mu \mathrm{g} / \mu \mathrm{l}$, for Staphylococcus saprophyticus at a concentration of $6.67 \mu \mathrm{g} / \mu \mathrm{l}$, and for Klebsiella pneumoniae at a concentration of $13.36 \mu \mathrm{g} / \mu \mathrm{l}$. The data obtained from testing for the determination of fungicidal activity showed that the extract has activity against the test culture of Candida albicans at a concentration of $0.21 \mu \mathrm{g} / \mu \mathrm{l}$. In addition, when tested by the disk-diffusion method, it was also found that the extract had an antimicrobial activity with high values of the growth suppression zone exceeding $15 \mathrm{~mm}$. The growth inhibition zones of the test strains were $19.33 \pm 1.15$ against Staphylococcus aureus, $17.33 \pm 3.21$ against Escherichia coli, $15.67 \pm 0.57$ against Pseudomonas aeruginosa, 20.0 \pm 1.0 against Streptococcus pneumoniae, $16.0 \pm 2.64$ against Klebsiella pneumoniae, $15.0 \pm 1.0$ against Staphylococcus saprophyticus, and $22.0 \pm 1.73$ against Candida albicans. Also, this extract has a bacteriostatic effect against the clinical isolate of Staphylococcus haemolyticus.

The results obtained for the test sample indicate the prospects for further study of the Malva thuringiaca (Lavatera thuringiaca L.) for medical practice.

\section{Data Availability}

The data used to support the findings of this study are available upon request.

\section{Conflicts of Interest}

The authors declare that there are no conflicts of interest regarding the publication of this article.

\section{Acknowledgments}

The authors would like to thank the faculty, as well as the Ph.D. doctoral students of the Faculty of Pharmacy and Pharmaceutical Technology, for their support in this work.

\section{References}

[1] A. Mocan, G. Zengin, A. Uysal et al., "Biological and chemical insights of Morina persica L.: a source of bioactive compounds with multifunctional properties," Journal of Functional Foods, vol. 25, pp. 94-109, 2016.

[2] M. S. Baytenov, Flora of Kazakhstan. Generic Flora Complex, The Gylym Publishing House, vol. 2, p. 136, Almaty, Kazakhstan, 2001.

[3] L. M. Grudzinskaya, N. G. Gemedzhieva, N. V. Nelina, and Z. H. Karzhaubekova, Annotated List of Medicinal Plants in Kazakhstan: A reference Book, Vol. 99, Leningrad: Publishing House of the USSR Academy of Sciences, Leningrad, Russia, 2014.

[4] N. V. Pavlova, Flora of Kazakhstan, vol. 6, pp. 146-147, AlmaAta: Publishing House of the Academy of Sciences of the Kazakh SSR, Almaty, Kazakhstan, 1963.

[5] I. Matławska, M. Sikorska, and W. Bylka, "Flavonoid compounds in Lavatera thuringiaca L. (Malvaceae) flowers," Acta Poloniae Pharmaceutica, vol. 56, pp. 453-458, 1999.

[6] E. Tuzlaci, D. F. A. İşbilen, and G. Bulut, "Turkish folk medicinal plants, VIII: lalapasa (Edirne)," Marmara Pharmaceutcal Journal, vol. 1, no. 14, pp. 47-52, 2010. 
[7] L. M. Fedoseeva and O. A. Myznikova, "Study of qualitative composition of phenol compounds in various parts of garden tree-mallow which grows in the territory of the Altai Krai," Medical Almanac, vol. 5, no. 50, pp. 167-174, 2017.

[8] S. Ramproshad, T. Afroz, B. Mondal et al., "Epilepsy," Neurology and Pregnancy, vol. 3, pp. 82-87, 2012.

[9] K. Ghosh, "A furocoumarin, Imperatorin isolated from Urena lobata L. (Malvaceae)," Molbank, vol. 2004, no. 1, Article ID M382, 2004.

[10] S. Kalayou, M. Haileselassie, G. Gebre-egziabher et al., "Invitro antimicrobial activity screening of some ethnoveterinary medicinal plants traditionally used against mastitis, wound and gastrointestinal tract complication in Tigray region, Ethiopia," Asian Pacific Journal of Tropical Biomedicine, vol. 2, no. 7, pp. 516-522, 2012.

[11] P. Maskovic, M. Radojkovic, M. Ristic, and S. Solujic, "Studies on the antimicrobial and antioxidant activity and chemical composition of the essential oils of Kitaibelia vitifolia," Natural Product Communications, vol. 8, no. 5, pp. 667-670, 2013.

[12] P. Z. Maškovića, V. Veličkovićb, S. Đurovićcd et al., "Biological activity and chemical profile of Lavatera thuringiaca L. extracts obtained by different extraction approaches," Phytomedicine, vol. 38, pp. 118-124, 2017.

[13] I. Matlawska, "Investigation of flavonoid compounds of selected SPP from Malvaceae family," Herba Polonica, vol. 36, no. 3, pp. 65-69, 1990.

[14] J. Dai and R. J. Mumper, "Plant phenolics: extraction, analysis and their antioxidant and anticancer properties," Molecules, vol. 15, no. 10, pp. 7313-7352, 2010.

[15] L. Petrovic, Z. Lepojevic, V. Sovilj, D. Tesevic, and V. Tešević, "An investigation of $\mathrm{CO}_{2}$ extraction of marigold (Calendula officinalis L.)," Journal of the Serbian Chemical Society, vol. 72, no. 4, pp. 407-413, 2007.

[16] CLSI, Performance Standards for Antimicrobial, Susceptibility Testing, vol. 35, no. 3, M100-S25, Wayne, PA, USA, 2015.

[17] MUK, Guidelines for Determining the Sensitivity of Microorganisms to Antibacterial Drugs, MUK, Moscow, Russia, 2004.

[18] CLSI, Reference Method for Broth Dilution Antifungal Susceptibility Testing of Yeast, CLSI, vol. 22, no. 15, Wayne, PA, USA, 2017.

[19] M. I. G. Silva, M. R. de Aquino Neto, P. F. Teixeira Neto et al., "Central nervous system activity of acute administration of isopulegol in mice," Pharmacology Biochemistry and Behavior, vol. 88, no. 2, pp. 141-147, 2007.

[20] M. I. G. Silva, M. A. G. Silva, M. R. de Aquino Neto et al., "Effects of isopulegol on pentylenetetrazol-induced convulsions in mice: possible involvement of GABAergic system and antioxidant activity," Fitoterapia, vol. 80, no. 8, pp. 506-513, 2009.

[21] M. I. G. Silva, B. A. Moura, M. R. de Aquino Neto et al., "Gastroprotective activity of isopulegol on experimentally induced gastric lesions in mice: investigation of possible mechanisms of action," Naunyn-Schmiedeberg's Archives of Pharmacology, vol. 380, no. 3, pp. 233-245, 2009.

[22] E. A. Laude, A. H. Morice, and T. J. Grattan, "The antitussive effects of menthol, camphor and cineole in conscious Guineapigs," Pulmonary Pharmacology, vol. 7, no. 3, pp. 179-184, 1994.

[23] N. Galeotti, L. Di Cesare Mannelli, G. Mazzanti, A. Ghelardini, and C. Ghelardinia, "Menthol: a natural analgesic compound," Neuroscience Letters, vol. 322, no. 3, pp. 145-148, 2002.
[24] D. N. Willis, B. Liu, M. A. Ha, S. E. Jordt, and J. B. Morris, "Menthol attenuates respiratory irritation responses to multiple cigarette smoke irritants," The FASEB Journal, vol. 8, pp. 4434-4444, 2011.

[25] C. .W. Yu, W. H. Li, F. L. Hsu, P. L. Yen, S. T. Chang, and V. H. C. Liao, "Essential oil alloaromadendrene from mixedtype cinnamomum osmophloeum leaves prolongs the lifespan in Caenorhabditis elegans," Journal of Agricultural and Food Chemistry, vol. 62, no. 26, pp. 6159-6165, 2014.

[26] D. P. Sousaa, F. F. F. Nóbregab, M. R. V. Limab, and R. N. Almeidab, "Pharmacological activity of (R)-(+)-Pulegone, a chemical constituent of essential oils," Zeitschrift für Naturforschung C, vol. 66, no. 7-8, pp. 353-359, 2011.

[27] C. R. Nogueira, L. H. Carbonezi, C. T. Floresde Oliveira, W. Silva Garcez, and F. Rodrigues Garcez, "Sesquiterpene derivatives from Ocotea minarum leaves," Phytochemistry Letters, vol. 42, pp. 8-14, 2021.

[28] J. S. Chaves, P. C. Leal, L. Pianowisky, and J. B. Calixto, "Pharmacokinetics and tissue distribution of the sesquiterpene alpha-humulene in mice," Planta Medica, vol. 74, no. 14, pp. 1678-1683, 2008.

[29] A. P. Rogerio, E. L. Andrade, D. F. P. Leite, C. P. Figueiredo, and J. B. Calixto, "Preventive and therapeutic anti-inflammatory properties of the sesquiterpene $\alpha$-humulene in experimental airways allergic inflammation," British Journal of Pharmacology, vol. 158, no. 4, pp. 1074-1087, 2009.

[30] S. Santoyo, S. Cavero, L. Jaime, E. Ibañez, F. J. Señoráns, and G. Reglero, "Chemical composition and antimicrobial activity of rosmarinus officinalis L. essential oil obtained via supercritical fluid extraction," Journal of Food Protection, vol. 68, no. 4, pp. 790-795, 2005.

[31] C. G. F. Melo, P. R. R. Salgado, D. V. Fonsêca et al., "Anticonvulsive activity of (1S)-(-)-verbenone involving RNA expression of BDNF, COX-2, and C-fos," NaunynSchmiedeberg's Archives of Pharmacology, vol. 390, no. 9, pp. 863-869, 2017.

[32] Q. Hu, G. S. Lin, W. G. Duan, M. Huang, and F. H. Lei, "Synthesis and biological activity of novel (Z)- and (E)-verbenone oxime esters," Molecules, vol. 22, no. 10, 2017.

[33] M. J. Chavan, P. S. Wakte, and D. B. Shinde, "Analgesic and anti-inflammatory activity of Caryophyllene oxide from Annona squamosa L. bark," Phytomedicine, vol. 17, no. 2, pp. 149-151, 2010.

[34] D. Yang, L. Michel, J. P. Chaumont, and J. Millet-Clerc, "Use of caryophyllene oxide as an antifungal agent in an in vitro experimental model of onychomycosis," Mycopathologia, vol. 148, pp. 79-82, 2000.

[35] S. J. Lee, J. I. Han, G. S. Lee et al., “Antifungal effect of eugenol and nerolidol against microsporum gypseum in a Guinea pig model," Biological and Pharmaceutical Bulletin, vol. 30, no. 1, pp. 184-188, 2007.

[36] J. D. N. Neto, A. A. C. Almeida, J. S. Oliveira, P. S. D. Santos, D. P. Sousa, and R. M. Freitas, "Antioxidant effects of nerolidol in mice Hippocampus after open field test," Neurochemical Research, vol. 38, no. 9, pp. 1861-1870, 2013.

[37] K. F. Nascimento, F. M. F. Moreira, J. A. Santos et al., "Antioxidant, anti-inflammatory, antiproliferative and antimycobacterial activities of the essential oil of psidium guineense Sw. and Spathulenol," Journal of Ethnopharmacology, vol. 210, pp. 351-358, 2018.

[38] S. Kim, E. Jung, J. H. Kim, Y. H. Park, J. Lee, and D. Park, "Inhibitory effects of (-)- $\alpha$-bisabolol on LPS-induced inflammatory response in RAW264.7. macrophages," Food and Chemical Toxicology, vol. 49, no. 10, pp. 2580-2585, 2011. 
[39] P. P. Kamatou and A. M. Viljoen, "A review of the application and pharmacological properties of $\alpha$-bisabolol and $\alpha$-bisabolol-rich oils," Journal of the American Oil Chemists' Society, vol. 87, no. 1, pp. 1-7, 2010.

[40] N. F. M. Rocha, E. R. V. Rios, A. M. R. Carvalho et al., “Antinociceptive and anti -inflammatory activities of (-)- $\alpha$-bisabolol in rodents," Naunyn-Schmiedeberg's Archives of Pharmacology, vol. 384, no. 6, pp. 525-533, 2011.

[41] M. Forrer, E. M. Kulik, A. Filippi, and T. Waltimo, "The antimicrobial activity of alpha-bisabolol and tea tree oil against solobacterium moorei, a gram-positive bacterium associated with halitosis," Archives of Oral Biology, vol. 58, no. 1, pp. 10-16, 2013.

[42] N. M. Saeed, E. El-Demerdash, H. M. Abdel-Rahman, M. M. Algandaby, F. A. Al-Abbasi, and A. B. Abdel-Naim, "Anti-inflammatory activity of methyl palmitate and ethyl palmitate in different experimental rat models," Toxicology and Applied Pharmacology, vol. 264, no. 1, pp. 84-93, 2012.

[43] J. Li, W. Hu, J. J. Baldassare et al., "The ethanol metabolite, linolenic acid ethyl ester, stimulates mitogen-activated protein kinase and cyclin signaling in hepatic stellate cells," Life Sciences, vol. 73, no. 9, pp. 1083-1096, 2003.

[44] T. Schramm, "The effect of fatty acids on carcinogenesis. III. The effect of linolenic acid ethyl ester on 2-acetylaminofluorene induced carcinogenesis," Biologica et Medica Germanica, vol. 7, pp. 75-86, 1961.

[45] C. C. M. P. Santos, M. S. Salvadori, V. G. Mota et al., "Antinociceptive and antioxidant activities of phytol in vivo and in vitro models," The Journal of Neuroscience, vol. 2013, Article ID 949452, 9 pages, 2013.

[46] R. O. Silva, F. B. M. Sousa, S. R. B. Damasceno et al., "Inhibits the inflammatory response by reducing cytokine production and oxidative stress," Fundamental \& Clinical Pharmacology, vol. 28, no. 4, pp. 455-464, 2014.

[47] X. Chen, X. Zhao, Y. Deng, X. Bu, H. Ye, and N. Guo, "Antimicrobial potential of myristic acid against listeria monocytogenes in milk," The Journal of Antibiotics, vol. 72, no. 5, pp. 298-305, 2019.

[48] R. Rezaee, E. Behravan, J. Behravan et al., "Antigenotoxic activities of the natural dietary coumarins umbelliferone, Herniarin and 7-isopentenyloxy coumarin on human lymphocytes exposed to oxidative stress," Drug and Chemical Toxicology, vol. 37, no. 2, pp. 144-148, 2014.

[49] M. B. Nayeli, H. R. Maribel, J. F. Enrique et al., "Anti-inflammatory activity of coumarins isolated from Tagetes lucida cav," Natural Product Research, vol. 8, pp. 1-5, 2019.

[50] B. V. Cheriyan, P. Kadhirvelu, J. Nadipelly, J. Shanmugasundaram, and V. Subramanian, "Anti-nociceptive effect of 7-methoxy coumarin from eupatorium Triplinerve vahl (asteraceae)," Pharmacognosy Magazine, vol. 13, no. 49, pp. 81-84, Article ID 197650, 2017.

[51] N. A. Habib, C. B. Wood, K. Apostolov et al., "Stearic acid and carcinogenesis," British Journal of Cancer, vol. 56, no. 4, pp. 455-458, 1987.

[52] G. Andreia, R. Snoecka, J. Neytsa, M. L. Sandvoldb, F. Myhrenb, and E. Clercqa, "Antiviral activity of ganciclovir elaidic acid ester against herpesviruses," Antiviral Research, vol. 45, no. 3, pp. 157-167, 2000.

[53] D. Kusumah, M. Wakui, M. Murakami, X. Xie, K. Yukihito, and I. Maeda, "Linoleic acid, $\alpha$-linolenic acid, and monolinolenins as antibacterial substances in the heat-processed soybean fermented with rhizopus oligosporus," Bioscience, Biotechnology, and Biochemistry, vol. 84, no. 6, pp. 1285-1290, 2020.
[54] A. R. Jalalvanda, M. Zhalehb, S. Gooranic et al., "Chemical characterization and antioxidant, cytotoxic, antibacterial, and antifungal properties of ethanolic extract of Allium Saralicum R. M. fritsch leaves rich in linolenic acid, methyl ester," Journal of Photochemistry and Photobiology B, vol. 192, pp. 103-112, 2019.

[55] T. H. Tu, H. Kim, S. Yang, J. K. Kim, and J. G. Kim, "Linoleic acid rescues microglia inflammation triggered by saturated fatty acid," Biochemical and Biophysical Research Communications, vol. 513, no. 1, pp. 201-206, 2019.

[56] K. B. Kim, Y. A. Nam, H. S. Kim, A. W. Hayes, and B. M. Lee, " $\alpha$-linolenic acid: nutraceutic $\Gamma$ al, pharmacological and toxicological evaluation," Food and Chemical Toxicology, vol. 70, pp. 163-178, 2014.

[57] C. L. Frías-Soria, D. Pérez-Pérez, S. Orozco-Suárez, and L. Rocha, "Cannabidiol modifies the seizure expression and effects of antiseizure drugs in a rat model of recurrent severe seizures seizure," Seizure, 2021.

[58] R. S. Darwish, H. M. Hammoda, D. A. Ghareeb et al., "Efficacy-directed discrimination of the essential oils of three Juniperus species based on their in-vitro antimicrobial and anti-inflammatory activities," Journal of Ethnopharmacology, vol. 259, Article ID 112971, 2020.

[59] A. R. Shahverdi, F. Rafii, M. R. Fazeli, and H. Jamalifar, "Enhancement of antimicrobial activity of furazolidone and nitrofurantoin against clinical isolates of Enterobacteriaceae by piperitone," International Journal of Aromatherapy, vol. 14, no. 2, pp. 77-80, 2004.

[60] M. I. Tleubayeva, U. M. Datkhayev, M. Alimzhanova, and N. Gemejiyeva, "Component composition and antimicrobial activity of $\mathrm{CO}_{2}$ extract of Portulaca oleracea, growing in the territory of Kazakhstan," Scientific World Journal, vol. 2021, Article ID 5434525, 10 pages, 2021. 